ISSN 1678-3921

Journal homepage: www.embrapa.br/pab

For manuscript submission and journal contents, access: www.scielo.br/pab

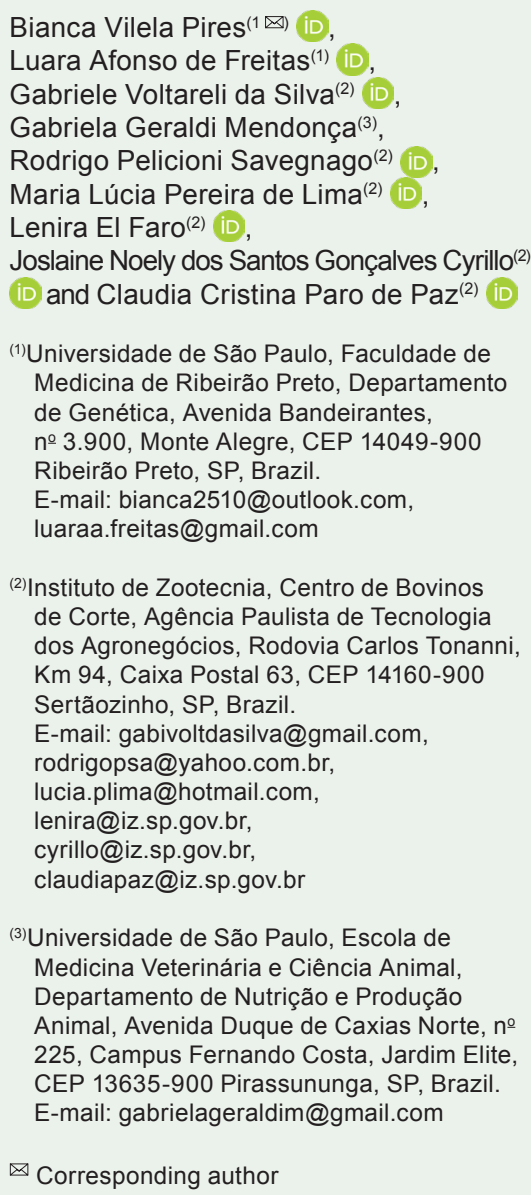

Received

May 22, 2019

Accepted

April 09, 2020

How to cite

PIRES, B.V.; FREITAS, L.A. de; SILVA, G.V. da: MENDONCA, G.G.: SAVEGNAGO, R.P. LIMA, M.L.P. de; EI FARO, L.; CYRILLO, J.N. dos S.G.; PAZ, C.C.P. de. Maternal-offspring behavior of Guzerat beef cattle. Pesquisa Agropecuária Brasileira, v.55, e01504, 2020. DOI: https://doi.org/10.1590/S1678-3921. pab2020.v55.01504.

\section{Maternal-offspring behavior of Guzerat beef cattle}

\begin{abstract}
The objective of this work was to evaluate the characteristics of the maternal-offspring behavior of Guzerat bovines (Bos indicus) and the influence of this behavior on herd losses. A total of 73 gestating cows (multiparous and primiparous) and their respective calves were evaluated for the following behavioral traits: contact period between cow and calf (CPCC), cow age at calving, teat conditions, calf vigor at birth, need for human assistance (HA), and calf mortality until weaning. The mean weight of calves at birth was $29.12 \mathrm{~kg}$. Vigor at birth was observed in $61.64 \%$ of calves; however, $27.4 \%$ of the calves required human assistance. Calf vigor was influenced by the CPCC, and calves without vigor needed more time with their mothers. Calves with low weight at birth required HA, whereas calves from cows with intermediate-sized teats did not. The absence of vigor at birth increased the mortality rate. The traits age of cows and vigor of calves at birth influence both the need for human assistance to calves in their first hours of life and herd losses.
\end{abstract}

Index terms: calf, maternal ability, survival.

\section{Comportamento materno-filial em bovinos de corte da raça Guzerá}

Resumo - O objetivo deste trabalho foi avaliar as características do comportamento materno-filial em animais da raça Guzerá (Bos indicus) e a influência desse comportamento nas perdas do rebanho. Utilizaramse 73 fêmeas (multíparas e primíparas) e seus respectivos bezerros para avaliação das seguintes características comportamentais: tempo de contato entre vaca e bezerro (CPCC), idade da vaca ao parto, características do teto, vigor do bezerro ao nascimento, necessidade de assistência humana (HA) e mortalidade até o desmame. A massa média dos bezerros ao nascimento foi de $29,12 \mathrm{~kg}$. O vigor ao nascimento foi observado em $61,64 \%$ dos bezerros; no entanto, $27,4 \%$ dos bezerros necessitaram de HA. O vigor dos bezerros foi influenciado pelo CPCC, e bezerros sem vigor necessitaram de maior tempo com suas mães. Bezerros com baixo peso ao nascer precisaram de HA, mas bezerros de vacas com tetas de tamanho intermediário não. A ausência de vigor ao nascimento aumentou a taxa de mortalidade. As características idade da vaca e vigor dos bezerros ao nascimento influenciam tanto a necessidade de assistência humana aos bezerros, nas primeiras horas de vida, como as perdas no rebanho.

Termos para indexação: bezerro, cuidado materno, sobrevivência.

\section{Introduction}

The productivity of beef cattle is guaranteed by a rate of one calf per cow a year. Several factors are associated with the birth and growth 
rates of the animals, and one of them is the maternaloffspring behavior. The behavior of calves and their mothers, during the first hours after calving, is a crucial factor for calf survival and development.

For beef cattle, the recognition between the calf and its mother, the nursing time, and the environmental temperature at parturition are factors that influence the calf's first actions after birth (Lidfors \& Jensen, 1988; Jensen, 2011). After calving, the calf tends to perform its first movements, such as shaking its head, trying to lean on its front limbs, and smelling its mother, until it can stand up and search for its first food - the colostrum (Paranhos da Costa et al., 2008; Broom \& Fraser, 2015).

Guzerat breed is a significant representative of Zebu cattle in Brazil, and it is characterized by hardiness, parasite resistance, responsiveness towards its offspring, and adaptability to tropical climates. It is considered a dual-purpose breed, with the majority assigned to beef cattle, and the rest to the dairy industry (Fonseca et al., 2016). The Guzerat herd has shown issues in maternal behavior after calving, and their temperament is a complication factor (Peixoto et al., 2016), which can result in a low-birth rate associated with a high-mortality rate among calves.

The mortality rate in Brazilian beef herds is about from 8 to 10\% (Corrêa et al., 2001; Azevedo Júnior et al., 2017; Magalhães Silva et al., 2017). These authors reported that the highest percentage of calf mortality occurs in the first weeks of life. Perinatal mortality is associated with difficulties in the parturition, extreme weights at birth (Bunter et al., 2014), and maternal ability (Riley et al., 2004; Schmidek et al., 2013), including nursing and protection after birth (Magalhães Silva et al., 2017).

Newborn calves are prone to diseases, thus, they need to acquire a passive immunity from the colostrum intake. Calf nursing is an essential factor for the acquisition of immunity and development, and it is advised to occur in up to 3 hours of life (Veissier et al., 2013). When evaluating the behavior of Guzerat and Nellore calves, Schmidek et al. (2006) verified a higher-mortality rate $(17.5 \%)$ in animals that did not nurse during the first three hours postpartum, in comparison to those that did it (4.0\%).

Calf susceptibility after calving increases the losses of livestock production. Calves without vigor at birth tend to be more fragile, and are more likely to acquire diseases; in addition, they do not reach the desired weights in weaning. Calf performance until weaning is influenced mainly by the maternal care during the first hours of life, as well as by calf vigor and gestational traits, which guarantees safety and survival during early life (Jensen, 2011; Arnott et al., 2012).

Studies evaluating the maternal care in Zebu breeds, discussed the effects on the preconception period caused by the environmental conditions (Grewal et al., 2019), calving difficulty, growth rate (Cortés-Lacruz et al., 2017; Rainforth, 2019), genetic traits (Magalhães Silva et al., 2017), and diet (Miguel-Pacheco et al., 2019; Noya et al., 2019). Nevertheless, studies on the behavioral traits in the relation of calf and cow in postparturition, and the behavior effects associated with the efficiency in herds are scarcely studied. Currently, there is scant information on the maternal-offspring behavior of Guzerat breed, therefore, studies on this matter could improve the management of the breed and decrease herd loss.

The objective of this work was to evaluate the characteristics of the maternal-offspring behavior of Guzerat bovines and the influence of this behavior on herd losses.

\section{Materials and Methods}

This work was carried out at the BeefCattle Research Center, in the Instituto de Zootecnia of the São Paulo state agency - Agência Paulista de Tecnologia dos Agronegócios, in the municipality of Sertãozinho $\left(21^{\circ} 17^{\prime} \mathrm{S}, 48^{\circ} 12^{\prime} \mathrm{W}\right)$, in the state of São Paulo, Brazil.

For the experiment, 73 pasture-raised Guzerat females, a genetically representative Guzerat herd, were used in a completely randomized experimental design, following the guidelines for animal welfare according to the State Law no. 11977 of São Paulo state, Brazil (São Paulo, 2005).

The breeding season occurred from November 2014 to February 2015 (90 days), through natural breed. Six Guzerat sires were used in the breeding season. The sires were selected according to the animal breeding program, in which a selected sire from 2 to 3 years of age is chosen based on the lack of relatedness with the females. The studied cows were born between 2001 and 2012, with initial ages from 2.5 to 14 years. The birth season occurred between September and 
November 2015, when 73 calves were evaluated (34 females, and 39 males).

Calving was observed during the day, between 07:00 $\mathrm{h}$ and 19:00 $\mathrm{h}$, when the cow-calf relationship was analyzed until 4 hours after birth, or until the first nursing. Notes were taken on the early signs of parturition (intense secretion, and exposure of fetal annexes) by focal sampling, with binoculars, at 5-min intervals, respecting the distance between the observer and the animals.

Calvings that occurred outside the observation interval (between 7:00 $\mathrm{h}$ and 19:00 h) were disregarded. Measurements of the interaction between calf and cow were performed using a timer. Observations concerning the management, cow traits, and calf vigor were also recorded. Birth weight (BW) was measured using an electronic scale after 4 hours of birth, or after the first nursing; and there was no interference in the maternal-offspring relationship. Mortality included all calves that died until weaning (approximately 7 months of age). Stillborn calves were disregarded.

The contact period between cow and calf (CPCC), which corresponds to the duration, in minutes, in which the cow smelled, licked, and followed the calf after parturition, was observed. The teat size (Teat) was visually evaluated and classified as large (1), intermediate (2), and small (3), according to Peixoto et al. (2014). In addition, the cows were classified according to age at calving (AC), as: primiparous cows, 3-year-old females (first calving); mature cows 1, between 4 and 7-year-old females; and mature cows 2 , females of 8 or more years of age.

The behavior analysis of calves began after the animals were entirely on the ground. The first trait attributed to calf was the absence (0) or presence (1) of vigor, based on the animal's motility during the first hour of life, according to Godfrey et al. (1991), who defined vigor as the calf's ability to survive without assistance. In addition to vigor, the calf's need of human assistance and mortality rate until weaning were also measured. The calves were classified according to whether they required human assistance; if they received assistance, HA was equal to 1 , and if not, HA was equal to 0 , after 4 hours of birth.

Descriptive statistical analyses were performed using the SAS program (SAS Institute, Inc., Cary, NC, USA). To analyze types 0 and 1 , a binomial distribution was used, a particular case of the generalized linear models (McCullagh \& Nelder, 1989). The occurrence or not of vigor, HA, and mortality was assessed using the logistic model with the Probit link function of the GENMOD procedure (SAS Inst., Inc., Cary, NC, USA). The selection of the effects included in the model was performed according to the Bayesian inference criterion (BIC).

For vigor trait, the fixed effects of the statistical model were sex, CPCC and $\mathrm{AC}$, and the random effect of the bull. For the analysis of HA, the model included the fixed effects of sex, CPCC, AC, BW, and teat size. For the mortality evaluation, the fixed effects of sex, AC, and vigor were considered in the model. The binomial logistic regression (Proc Logistic - SAS) was applied to obtain estimates of the odds ratios, and 95\% confidence intervals were for the vigor, HA, and mortality variables, among the classes of significant effects $(p<0.05)$. This procedure helped with the interpretation of the magnitude and direction of the associations between the exposures and the occurrence of mortality, vigor, and human assistance of the calves (Hosmer et al., 2013). Regarding the fixed effects composed of two classes ( 0 or 1$)$, in which the odds ratio was equal to 1 , the classes did not differ from each other and, thus, they had the same chance of occurrence. The odds ratio was tested for problem incidence (vigor $=0$, human assistance $=1$, and mortality $=1$ ), in which the chosen reference classes were those that displayed the least occurrence of the problem.

Subsequently, the principal component analysis was performed on a correlation matrix, using the Princomp SAS procedure. This method reduces the data size and groups the variables with greater similarity (Cruz Júnior et al., 2016). The variables considered in this analysis were mortality, vigor, $\mathrm{HA}, \mathrm{AC}$, teat, $\mathrm{BW}$, sex, and CPCC.

\section{Results and Discussion}

Among the evaluated cows, $16.44 \%$ were primiparous, $57.53 \%$ were mature cows 1 , and $26.03 \%$ were mature cows 2 . The high concentration of cows with four to seven years of age in the herd is a positive point for livestock production. The cow rotation in herd helps to reduce the effects of cow age at calving (Taylor et al., 2017). For teat size, $15.07 \%$ of cows showed large teats, $73.97 \%$ showed intermediate ones, and $10.96 \%$ 
showed small teat sizes (Table 1). This result indicates that the traits of the mammary system in these cows are good. The newborn nursing difficulty is higher when cows have small or large teats (Schmidek et al., 2008).

The mean BW was $29.12 \pm 4.9 \mathrm{~kg}$; this is the expected range in Zebu cattle, which corroborates the birth weight found by Ferreira et al. (2017) in Guzerat breed. HA was required for $27.4 \%$ of the calves, $72.6 \%$ of which achieved an adequate performance and were able

Table 1. Number of observations and relative frequency of variables: sire, sex, birth weight, mortality, cow and calf contact duration (CPCC), teat size, cow age at calving, vigor of calf, and human assistance according to the classification of Guzerat breed.

\begin{tabular}{|c|c|c|}
\hline Variables and categories & $\begin{array}{c}\text { No. of } \\
\text { observations }\end{array}$ & $\begin{array}{c}\text { Relative } \\
\text { frequency }(\%)\end{array}$ \\
\hline \multicolumn{3}{|l|}{ Sire } \\
\hline 959 & 11 & 15.06 \\
\hline 1002 & 19 & 26.03 \\
\hline 1006 & 18 & 24.66 \\
\hline 1063 & 10 & 13.70 \\
\hline 1077 & 9 & 12.33 \\
\hline 1105 & 6 & 8.22 \\
\hline \multicolumn{3}{|l|}{ Calf sex } \\
\hline Male & 39 & 53.43 \\
\hline Female & 34 & 46.57 \\
\hline \multicolumn{3}{|l|}{ Birth weight (BW) } \\
\hline$\leq 28 \mathrm{~kg}$ & 33 & 45.21 \\
\hline$\geq 29 \mathrm{~kg}$ & 40 & 54.79 \\
\hline \multicolumn{3}{|l|}{ Mortality } \\
\hline 0 & 63 & 86.30 \\
\hline 1 & 10 & 13.70 \\
\hline \multicolumn{3}{|l|}{$\mathrm{CPCC}$} \\
\hline$<30 \min$ & 23 & 31.51 \\
\hline $30-60 \min$ & 28 & 38.36 \\
\hline$>60 \mathrm{~min}$ & 16 & 21.92 \\
\hline Lost data & 6 & 8.21 \\
\hline \multicolumn{3}{|l|}{ Teat size } \\
\hline Large & 11 & 15.07 \\
\hline Intermediate & 54 & 73.97 \\
\hline Small & 8 & 10.96 \\
\hline \multicolumn{3}{|l|}{ Cow age at calving (AC) } \\
\hline Primiparous $(\leq 3$ years $)$ & 12 & 16.44 \\
\hline Mature cows 1 ( 4 to 7 years) & 42 & 57.53 \\
\hline Mature cows 2 ( $\geq 8$ years) & 19 & 26.03 \\
\hline \multicolumn{3}{|l|}{ Vigor of calf $(\mathrm{V})$} \\
\hline 0 & 28 & 38.36 \\
\hline 1 & 45 & 61.64 \\
\hline \multicolumn{3}{|l|}{ Human assistance (HA) } \\
\hline 0 & 53 & 72.60 \\
\hline 1 & 20 & 27.40 \\
\hline
\end{tabular}

to suckle during the first 4 hours postpartum. Previous studies on bovines have shown that the mortality risk increases, and the growth rate decreases, in calves that show difficulty in colostrum suction, after 3 hours of birth (Das et al., 2000; Schmidek et al., 2006; Veissier et al., 2013; Turner et al., 2013; Taylor et al., 2017). Therefore, the postpartum management is very important for the herd efficiency because the calf care could avoid losses in this period. Most of the calves $(61.64 \%)$ showed vigor at birth $(\mathrm{V}=1)$, while $38.36 \%$ showed no vigor $(\mathrm{V}=\mathrm{O})$ (Table 1$)$. For a production farm, a total of $38 \%$ of calves without vigor is a complication factor. In this situation, the monitoring of parturition, nursing and growth are the recommended (Vasseur et al., 2009; Arnott et al., 2012; Ring et al., 2018).

The calf mortality rate until weaning was $13.7 \%$ (Table 1), which corroborates those described in previous studies, from 3 to $15 \%$ until weaning (Bunter et al., 2014; Magalhães Silva et al., 2017; Ring et al., 2018). The need for human assistance and the vigor absence imply problems for calf development, as they indicate increasing chances of pre-weaning mortality. According to Bunter et al. (2014), in addition to the traits of the calf itself (vigor, weight, resistance), those of the cows (age, ease of calving, characteristics of their mammary system) are associated with offspring mortality.

Calf vigor at birth was influenced by the CPCC and $\mathrm{AC}$; however, the bull (father of calf) and the calf sex did not influence calf vigor. The calves without vigor were taken care of for a longer period by their mothers. For CPCC, it was observed that calves with vigor remained in contact with their mothers for less than $60 \mathrm{~min}$, differing from those without vigor, whose mothers spent more than $60 \mathrm{~min}$ in contact with them (Table 2). The time dedicated to maternal care in cattle varies according to calf conditions. Fragile animals (low-birth weight, without vigor, low motility) tend to receive a greater parental attention (Stěhulová et al., 2013). In a study on Holstein Friesian breed, Jensen (2011) verified that cows initially established contact with the newborn, but, afterward, the calf initiated the contact. Similarly, in the present study, the calf's behavior was stimulated by that of the cow. Whenever the cow lacked feedback from its offspring, it continued to smell and to lick it, until it reacted. 
The chances of a calf to show no vigor at birth, having CPCC lower than $30 \mathrm{~min}$, was 0.14 times lower than calves that had a CPCC greater than $60 \mathrm{~min}$. Whereas the chances of calves without vigor and with CPCC between 30-60 min were 0.12 times lower than calves with CPCC upper 60 min (Table 3). In Gascon breed, Stěhulová et al. (2013) observed that cows dedicated more time in taking care of male calves and calves with lower-birth weight. The present study corroborates their results, as the cows spent more than 60 min with calves without vigor, and male calves or those with lower-birth weight required their mother's care and HA.

Mature cows type 1 calved a higher percentage of animals without vigor at birth than the primiparous and mature cows type 2; this result may be attributed to differences in maternal care according to parity. The possibility of calves from mature cows type 1 not showing vigor at birth was 1.36 times lower than that of calves from primiparous cows. In other studies, different results were found, whereby primiparous cows have shown little maternal behavior with offspring (Edwards \& Broom, 1982; Geburt et al., 2015; Zipp et al., 2016).

Table 2. Frequency of the effects of calf sex, cow and calf contact duration (CPCC), bull, and cow age at calving in percentage, according to absence (0) or presence (1) of calf vigor at birth (V).

\begin{tabular}{lccc}
\hline Variable & \multicolumn{2}{c}{ Calf vigor at birth (\%) } & \multirow{2}{*}{ p-value ${ }^{(1)}$} \\
\cline { 2 - 3 } & Absence (0) & Presence (1) & \\
\hline Calf sex & & & 0.0831 \\
$\quad$ Male & 51.28 & 48.72 & \\
$\quad$ Female & 23.53 & 76.47 & \\
\hline CPCC & & & 0.0399 \\
$<30 \mathrm{~min}$ & 35.71 & 64.29 & \\
$30-60 \mathrm{~min}$ & 33.33 & 66.67 & \\
$>60$ min & 80.00 & 20.00 & \\
\hline Bull & & & 0.6014 \\
959 & 54.55 & 45.45 & \\
1002 & 36.84 & 63.16 & \\
1006 & 27.78 & 72.22 & \\
1063 & 50.00 & 50.00 & \\
1077 & 33.33 & 66.67 & \\
1105 & 33.33 & 66.67 & \\
\hline Cow age at calving (AC) & & & 0.0214 \\
Primiparous ( $\leq 3$ years) & 33.33 & 66.67 & \\
Mature cows 1 (4 to 7 years) & 40.48 & 59.52 & \\
Mature cows 2 ( $\geq 8$ years) & 36.84 & 63.16 & \\
\hline
\end{tabular}

${ }^{(1)}$ Significant at $5 \%$ probability.
Calf sex, BW, and teat determined the need for HA in the first hours of the calf's life (Table 4). Male calves exhibited a higher-relative risk for the need of HA in the first hours of life than to female calves (Table 5). Similar results were found for Brahman's male calves that showed a greater chance of absence vigor at birth than females (Riley et al., 2004). Male calves received

Table 3. Odds ratio analysis for the absence of vigor at birth (0), based on the effect of the cow and calf contact duration (CPCC) and cow age at calving in the Guzerat herd.

\begin{tabular}{lcc}
\hline Variable & \multicolumn{2}{c}{ Absence of vigor at birth } \\
\cline { 2 - 3 } & Odds ratio $^{(1)}$ & Confidence interval \\
\hline CPCC & 0.14 & $0.012-1.61$ \\
$<30$ min & 0.12 & $0.012-1.34$ \\
$30-60$ min & $\mathrm{RC}$ & $\mathrm{RC}$ \\
$>60 \mathrm{~min}$ & $\mathrm{RC}$ & $\mathrm{RC}$ \\
\hline Cow age at calving (AC) & 1.36 & $0.35-5.24$ \\
Primiparous ( $\leq 3$ years) & 1.17 & $0.25-5.33$ \\
Mature cows 1 (4 to 7 years) & \\
Mature cows 2 $(\geq 8$ years) & & \\
\hline
\end{tabular}

${ }^{(1)}$ Significant at $5 \%$ probability. RC, reference class meaning above $60 \mathrm{~min}$ of contact.

Table 4. Animal frequency (\%) regarding the need for human assistance (HA) to Guzerat calves, according to the calf sex, cow and calf contact duration (CPCC), birth weight, teat size, and cow age at calving.

\begin{tabular}{|c|c|c|c|}
\hline \multirow[t]{2}{*}{ Variable } & \multicolumn{2}{|c|}{ Human assistance (\%) } & \multirow[t]{2}{*}{ p-value } \\
\hline & 0 & 1 & \\
\hline Calf sex & & & 0.0009 \\
\hline Male & 69.23 & 30.77 & \\
\hline Female & 76.47 & 23.53 & \\
\hline CPCC & & & 0.8489 \\
\hline$<30 \min$ & 64.29 & 35.71 & \\
\hline $30-60 \min$ & 66.67 & 33.33 & \\
\hline$>60 \mathrm{~min}$ & 80.00 & 20.00 & \\
\hline Birth weight (BW) & & & 0.0466 \\
\hline$\leq 28 \mathrm{~kg}$ & 60.61 & 39.39 & \\
\hline$\geq 29 \mathrm{~kg}$ & 82.50 & 17.50 & \\
\hline Teat size & & & 0.0386 \\
\hline Large & 54.55 & 45.45 & \\
\hline Intermediate & 79.63 & 20.37 & \\
\hline Small & 50.00 & 50.00 & \\
\hline Cow age at calving (AC) & & & 0.5249 \\
\hline Primiparous ( $\leq 3$ years) & 75.00 & 25.00 & \\
\hline Mature cows 1 ( 4 to 7 years) & 76.19 & 23.81 & \\
\hline Mature cows 2 ( $\geq 8$ years $)$ & 63.16 & 36.84 & \\
\hline
\end{tabular}

(1) Significant at $5 \%$ probability. 
more maternal care than female ones, according to Stěhulová et al. (2013).

The need for HA in calves weighing up to $28 \mathrm{~kg}$ was considerably different from calves that for calves weighing more than $29 \mathrm{~kg}$. Calves with vigor required less time of motherly care, and those with more than $29 \mathrm{~kg}$ did not need HA. Such observation was distinct from those of animals with less than $28 \mathrm{~kg}$, who required their mother's care, in addition to HA. Calves with low weight at birth showed a greater difficulty to survive during the first days of life, thus requiring HA. However, cows are highly protective at this stage (Geburt et al., 2015); besides, to give HA to calves after birth can be a problematic achievement in extensive production systems, as the dams are more aggressive, and the management requires more care.

The cow teat classification influenced the calf's need for HA. In the present work, we observed that $79.63 \%$ of the calves from cows with intermediatesized teats did not require HA. In turn, $45.45 \%$ of the calves from cows with large teats, and $50 \%$ of the calves from cows with small teats, needed HA (Table 4). The odds ratio for calves that needed HA was 3.26 times higher in the offspring from cows with teats classified as large, and 3.90 times greater for calves from cows classified as having small teats, than those of cows with intermediate-sized teats (Table 5).

The mammary system conformation is a significant factor for newborn nursing and may interfere in animal development. The udder conformation is a good

Table 5. Odds ratio analysis regarding the need for human assistance (HA), based on the classificatory effects for calf sex, birth weight, and teat size of the Guzerat herd.

\begin{tabular}{|c|c|c|}
\hline \multirow[t]{2}{*}{ Variable } & \multicolumn{2}{|c|}{ Human assistance (HA) } \\
\hline & Odds ratio $^{(1)}$ & Confidence interval \\
\hline \multicolumn{3}{|l|}{ Calf sex } \\
\hline Male & 1.44 & $0.51-4.10$ \\
\hline Female & $\mathrm{RC}$ & $\mathrm{RC}$ \\
\hline \multicolumn{3}{|c|}{ Birth weight (BW) } \\
\hline$\leq 28 \mathrm{~kg}$ & 3.06 & $1.05-8.97$ \\
\hline$\geq 29 \mathrm{~kg}$ & $\mathrm{RC}$ & $\mathrm{RC}$ \\
\hline \multicolumn{3}{|l|}{ Teat size } \\
\hline Large & 3.26 & $0.84-12.68$ \\
\hline Intermediate & $\mathrm{RC}$ & $\mathrm{RC}$ \\
\hline Small & 3.90 & $0.84-18.16$ \\
\hline
\end{tabular}

${ }^{(1)}$ Significant at $5 \%$ probability. RC, female calves weight above $29.0 \mathrm{~kg}$ and with intermediate-sized teats. indicator for action to help the calf to suckle (Edwards \& Broom, 1982).

Cows that have large or very small teats pose a major challenge for their young during their first feeding, which implies a prolonged duration of colostrum suction and calf exhaustion, resulting in the need for HA. Calves from Zebu cows with larger or smaller teats showed a failure increasing at the first suckling, according to Paranhos da Costa et al. (2008), who suggest that, in order to avoid problems with parturient cows and neonates, inspections three times a day should be performed. After grabbing a small teat for the first time, the calf becomes accustomed to its size, and the difficulty in suckling reduces as the animal grows. In a study with the Brahman breed, tropically adapted composites breeds and their crosses, Bunter et al. (2014) related that cows with large teats (scores 4 and 5) increased the calf mortality from 4.12 to 4.49 . The same authors concluded that the teat size affects the nursing of calves, mainly if the udder and teats become further distended through an interruption for milk removal (small calf or weak at birth).

The mortality rate until weaning was $13.7 \%$, disregarding stillborn calves, and it was influenced by calf vigor at birth (Table 6). Our findings corroborate those for the probability of mortality for calves without vigor at birth, also reported by Riley et al. (2004), who described a positive correlation between low vigor at birth and high-mortality rates in Brahman herds. Calf vigor following parturition required more attention because of the negative consequences on calf's vigor, weight gain, behavior, and immunocompetence

Table 6. Mortality rate of calves until weaning in percentage and p-value, based on the effects of calf sex, cow age at calving, and calf vigor.

\begin{tabular}{|c|c|c|c|}
\hline \multirow[t]{2}{*}{ Variable } & \multicolumn{2}{|c|}{ Mortality rate } & \multirow[t]{2}{*}{ p-value } \\
\hline & 0 & 1 & \\
\hline Calf sex & & & 0.5345 \\
\hline Male & 82.05 & 17.95 & \\
\hline Female & 91.18 & 8.82 & \\
\hline Cow age at calving (AC) & & & 0.9333 \\
\hline Primiparous ( $\leq 3$ years) & 83.33 & 16.67 & \\
\hline Mature cows 1 ( 4 to 7 years) & 88.10 & 11.90 & \\
\hline Mature cows 2 ( $\geq 8$ years $)$ & 84.21 & 15.79 & \\
\hline Calf vigor $(\mathrm{V})$ & & & 0.0495 \\
\hline Absence of vigor (0) & 75.00 & 25.00 & \\
\hline Presence of vigor (1) & 93.33 & 6.67 & \\
\hline
\end{tabular}

${ }^{(1)}$ Significant at $5 \%$ probability. 
(Murray et al., 2015). Cow and calf traits in Zebu breeds are poorly addressed in the literature, although responses regarding calf vigor are very useful for the success of a herd.

In the present study, the AC did not affect calf mortality. Studies performed in bovines (Zipp et al., 2016) and buffaloes (Dubey et al., 2018) report that the $\mathrm{AC}$ does not influence the behavioral responses of mothers. Differences observed for maternal behavior, such as readiness to initiate care and intensity of rejections, can be attributed to individual differences in the temperament of the mother and its previous reproductive experiences.

The odds for mortality was 4.66 times greater in calves that were born without vigor (reference class $=$ presence vigor), with a confidence interval between
1.09 and 19.90. Animals without vigor at birth required more time with their mothers and showed more difficulties to perform their first activities, increasing the mortality risks. This increment is due to the weakness of the calf, which fails to acquire a passive immunity through the colostrum ingestion, which results in an elevated susceptibility to pathogens, compromising its development (Taylor et al., 2017).

The association between the eight variables was explained by the principal components analysis. In this study, the first three principal components (PC) together accounted for $53.5 \%$ of the variability of the analyzed traits, in which PC 1, 2, and 3 explained 20.9, 17.3 , and $15.3 \%$ of the data variation, respectively. The variable vectors with a higher length within the main component can be used to separate the animals with

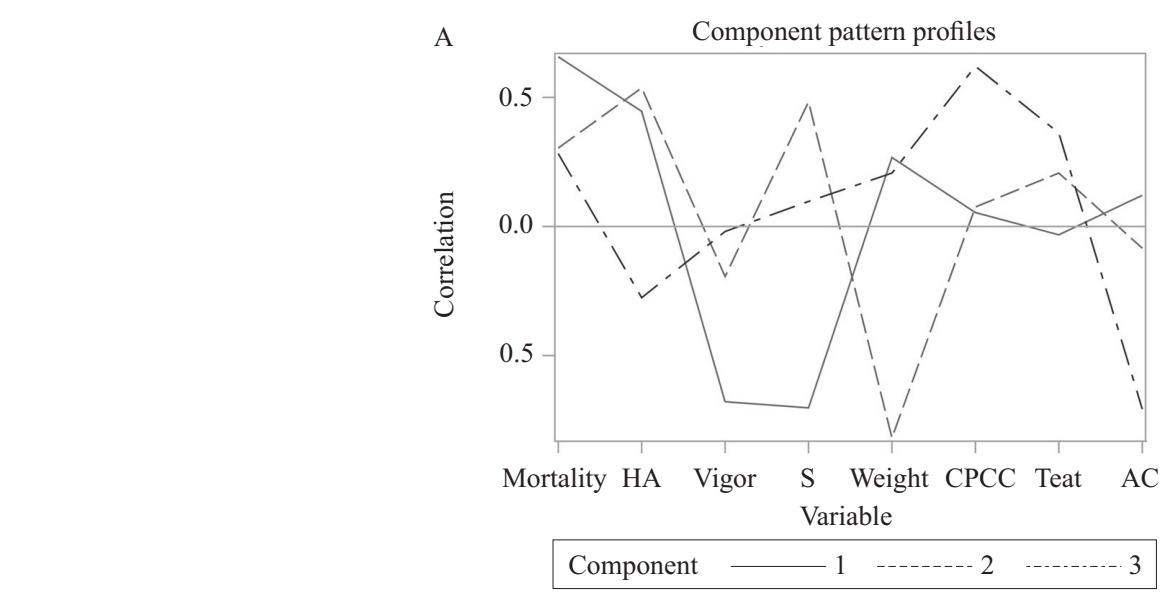

B Component pattern profiles

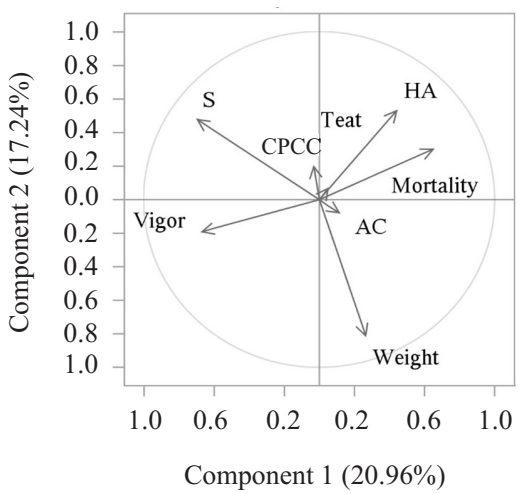

C

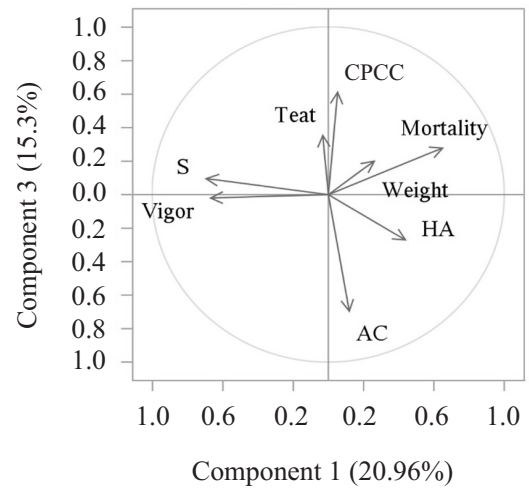

D Component pattern profiles

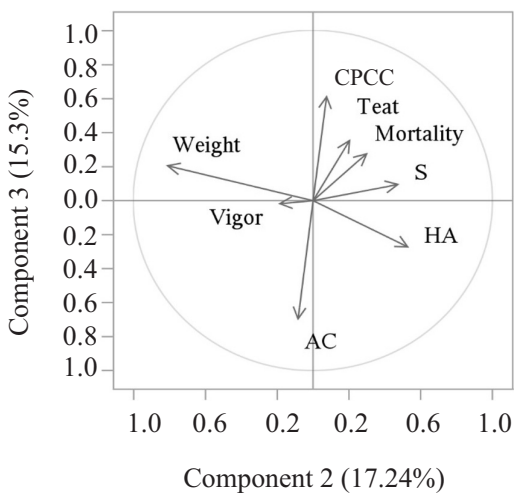

Figure 1. Principal component analysis based on the correlation between the variables. (A): mortality, calf mortality until weaning; HA, human assistance to offspring; vigor, calf vigor at birth $(0=$ without vigor, $1=$ with vigor $)$, S, calf sex; weight, weight of calf at birth; CPCC, contact period between cow and calf; teat, cow teat classification; AC, age of cow at calving. (B): vector graph between principal components 1 and 2. (C): vector graph between principal components 1 and 3. (D): vector graph between principal components 2 and 3 . 
antagonistic traits inside the main component. The mortality, vigor, and sex had a greater discriminant power in PC 1, showing the highest correlation. Mortality showed a negative correlation with vigor and sex. This result indicated that poor vigor on birth could increase the mortality rate (Figure 1).

The orthogonality between $\mathrm{PC} 1$ and $\mathrm{PC} 2$ axis variables indicated that $\mathrm{PC} 1$ had a low association with PC2. The BW and HA had a greater discriminant power in PC 2. Calves with an adequate weight during birth did not require HA. These animals get to achieve their first activities without human interference. When comparing PC 1 to PC 2, the traits of human assistance and mortality are opposed to calf vigor at birth. The calves without vigor in the birth tend to lead to an increase in mortality rate. The AC and CPCC showed a negative association in $\mathrm{PC} 3$, confirming the results found. The cow age at calving affects the care with the offspring. The teat and CPCC have the same beam direction, and the positive correlation in these traits indicates that the quality of the mammary system is fundamental for the success of calf suckling (Figure 1).

Thereby, animals with low-birth weight and without vigor generally exhibit several problems, including the refusal to voluntary suckling, which forces the human interference to ensure the acquisition of passive immunity (Arnott et al., 2012; Murray \& Leslie, 2013). Consequently, these animals require more time to attempt to standing, walking, and reaching the udder. These activities depend on many factors such as the cow age, nutrition during pregnancy, maternal ability, and calf vitality (Weaver et al., 2000; Grandinson, 2005; Vasseur et al., 2009; Murray \& Leslie, 2013).

This study provided information on what can be done to improve a herd for the quality of maternal behavior and, consequently, to increase the efficiency of the herd, decreasing the mortality rate.

\section{Conclusions}

1. The characteristics age of cows and vigor of calves at birth influence the need for human assistance to calves, in the first hours of life, as well as the herd losses.

2. Guzerat cows adapt their behavior according to the calves' requirements.

3. The management during the birth season by offering human assistance to the calves, in the first hours of life, and by promoting the rotation of the cows in the herd, minimizes the behavior influence on herd losses.

\section{Acknowledgments}

To Conselho Nacional de Desenvolvimento Científico e Tecnológico (CNPq), for productivity fellowships; and to Coordenação de Aperfeiçoamento de Pessoal de Nível Superior (Capes), for financial support (Finance code 001).

\section{References}

ARNOTT, G.; ROBERTS, D.; ROOKE, J.A.; TURNER, S.P.; LAWRENCE, A.B.; RUTHERFORD, K.M.D. Board invited review: The importance of the gestation period for welfare of calves: Maternal stressors and difficult births. Journal of Animal Science, v.90, p.5021-5034, 2012. DOI: https://doi.org/10.2527/ jas.2012-5463.

AZEVEDO JÚNIOR, J.; PETRINI, J.; MOURÃO, G.B.; FERRAZ, J.B.S. Preweaning calf survival of a Nellore beef cattle population. Journal of Agricultural Science, v.9, p.51-62, 2017. DOI: https://doi.org/10.5539/jas.v9n8p51.

BROOM, D.M.; FRASER, A.F. Domestic animal behaviour and welfare. $5^{\text {th }}$ ed. Wallingford: CABI, 2015. 472p.

BUNTER, K.L.; JOHNSTON, D.J.; WOLCOTT, M.L.; FORDYCE, G. Factors associated with calf mortality in tropically adapted beef breeds managed in extensive Australian production systems. Animal Production Science, v.54, p.25-36, 2014. DOI: https://doi.org/10.1071/AN12421.

CORRÊA, E.S.; EUCLIDES FILHO K.; ALVES, R.G.; VIERA, A. Desempenho reprodutivo em um sistema de produção de gado de corte. Campo Grande: Embrapa Gado de Corte, 2001. 33p. (Embrapa Gado de Corte. Boletim de pesquisa, 13).

CORTÉS-LACRUZ, X.; CASASÚS, I.; REVILLA, R.; SANZ, A.; BLANCO, M.; VILLALBA, D. The milk yield of dams and its relation to direct and maternal genetic components of weaning weight in beef cattle. Livestock Science, v.202, p.143-149, 2017. DOI: https://doi.org/10.1016/j.livsci.2017.05.025.

CRUZ JÚNIOR, C.A. da; LUCCI, C.M.; PERIPOLLI, V.; TANURE, C.B.; SILVA, A.F. da; MENEZES, A.M. de; RAMOS, A.F.; MCMANUS, C.M. Breed comparison for heat adaptation in rams using multivariate analysis. Bioscience Journal, v.32, p.178190, 2016. DOI: https://doi.org/10.14393/BJ-v32n1a2016-29741.

DAS, S.M.; REDBO, I.; WIKTORSSON, H. Effect of age of calf on suckling behaviour and other behavioural activities of Zebu and crossbred calves during restricted suckling periods. Applied Animal Behaviour Science, v.67, p.47-57, 2000. DOI: https://doi.org/10.1016/S0168-1591(99)00115-X.

DUBEY, P.; SINGH, R.R.; CHOUDHARY, S.S.; VERMA, K.K.; KUMAR, A.; GAMIT, P.M.; DUBEY, S.; PRAJAPATI, K. Post parturient neonatal behaviour and their relationship with maternal behaviour score, parity and sex in Surti buffaloes. Journal 
of Applied Animal Research, v.46, p.360-364, 2018. DOI: https://doi.org/10.1080/09712119.2017.1306533.

EDWARDS, S.A.; BROOM, D.M. Behavioural interactions of dairy cows with their newborn calves and the effects of parity. Animal Behaviour, v.30, p.525-535, 1982. DOI: https://doi.org/10.1016/S0003-3472(82)80065-1.

FERREIRA, J.L.; BRESOLIN, T.; LOPES, F.B.; GARCIA, J.A.S.; NEPOMUCENO, L.L.; SCHMIDT, A.B.; LOBO, R.B. Modelos de regressão aleatória para característica de crescimento em bovinos da raça Guzerá. Ciência Animal Brasileira, v.18, e-39566, 2017. DOI: https://doi.org/10.1590/1089-6891v18e-39566.

FONSECA, P.A. de S.; SANTOS, F.C. dos; ROSSE, I.C.; VENTURA, R.V.; BRUNELLI, F.Â.T.; PENNA, V.M.; SILVA VERNEQUE, R. da; MACHADO, M.A.; SILVA, M.V.G.B. da; CARVALHO, M.R.S.; PEIXOTO, M.G.C.D. Retelling the recent evolution of genetic diversity for Guzerá: Inferences from LD decay, runs of homozygosity and $\mathrm{Ne}$ over the generations. Livestock Science, v.193, p.110-117, 2016. DOI: https://doi.org/10.1016/j.livsci.2016.10.006.

GEBURT, K.; FRIEDRICH, M.; PIECHOTTA, M.; GAULY, M.; KÖNIG VON BORSTEL, U. Validity of physiological biomarkers for maternal behavior in cows - A comparison of beef and dairy cattle. Physiology \& Behavior, v.139, p.361-368, 2015. DOI: https://doi.org/10.1016/j.physbeh.2014.10.030.

GODFREY, R.W.; SMITH, S.D.; GUTHRIE, M.J.; STANKO, R.L.; NEUENDORFF, D.A.; RANDEL, R.D. Physiological responses of newborn Bos indicus and Bos indicus x Bos taurus calves after exposure to cold. Journal of Animal Science, v.69, p.258-263, 1991. DOI: https://doi.org/10.2527/1991.691258x.

GRANDINSON, K. Genetic background of maternal behaviour and its relation to offspring survival. Livestock Production Science, v.93, p.43-50, 2005. DOI: https://doi.org/10.1016/j. livprodsci.2004.11.005.

GREWAL, S.; AGGARWAL, A.; ALHUSSIEN, M.N. Integrated effects of season and parturition-associated stress on the inflammatory response and metabolic status in Sahiwal (Bos indicus) cows. Biological Rhythm Research, v.50, p.1-12, 2019. DOI: https://doi.org/10.1080/09291016.2019.1627657.

HOSMER JR., D.W.; LEMESHOW, S.; STURDIVANT, R.X. Applied logistic regression. $3^{\text {rd }}$ ed. New York: John Wiley \& Sons, 2013. 375p. DOI: https://doi.org/10.1002/0471722146.

JENSEN, M.B. The early behaviour of cow and calf in an individual calving pen. Applied Animal Behaviour Science, v.134, p.92-99, 2011. DOI: https://doi.org/10.1016/j.applanim.2011.06.017.

LIDFORS, L.; JENSEN, P. Behaviour of free-ranging beef cows and calves. Applied Animal Behaviour Science, v.20, p.237-247, 1988. DOI: https://doi.org/10.1016/0168-1591(88)90049-4.

MAGALHÃES SILVA, L.C.; BALDI, F.; ABOUJAOUDE, C.; VENTURINI, G.C.; ALBUQUERQUE, L.G.; PARANHOS DA COSTA, M.J.R. Genetic parameter estimates for prenatal and postnatal mortality in Nellore cattle. Journal of Animal Breeding and Genetics, v.134, p.27-33, 2017. DOI: https://doi.org/10.1111/jbg.12246.
MIGUEL-PACHECO, G.G.; PERRY, V.E.A.; HERNANDEZMEDRANO, J.H.; WAPENAAR, W.; KEISLER, D.H.; VOIGT, J.P. Low protein intake during the preconception period in beef heifers affects offspring and maternal behaviour. Applied Animal Behaviour Science, v.215, p.1-6, 2019. DOI: https://doi.org/10.1016/j.applanim.2019.04.003.

MCCULLAGH, P.; NELDER, J.A. Generalized linear models. $2^{\text {nd }}$ ed. London: Chapman and Hall, 1989. (Monographs on Statistic and Applied Probability, 37).

MURRAY, C.F.; LESLIE, K.E. Newborn calf vitality: risk factors, characteristics, assessment, resulting outcomes and strategies for improvement. The Veterinary Journal, v.198, p.322-328, 2013. DOI: https://doi.org/10.1016/j.tvj1.2013.06.007.

MURRAY, C.F.; VEIRA, D.M.; NADALIN, A.L.; HAINES, D.M.; JACKSON, M.L.; PEARL, D.L.; LESLIE, K.E. The effect of dystocia on physiological and behavioral characteristics related to vitality and passive transfer of immunoglobulins in newborn Holstein calves. Canadian Journal of Veterinary Research, v.79, p.109-119, 2015. DOI: https://doi.org/10.1016/j.livsci.2006.08.002.

NOYA, A.; SERRANO-PÉREZ, B.; VILLALBA, D.; CASASÚS, I.; MOLINA, E.; LÓPEZ-HELGUERA, I.; SANZ, A. Effects of maternal subnutrition during early pregnancy on cow hematological profiles and offspring physiology and vitality in two beef breeds. Animal Science Journal, v.90, p.857-869, 2019. DOI: https://doi.org/10.1111/asj.13215.

PARANHOS DA COSTA, M.J.R.; SCHMIDEK, A.; TOLEDO, L.M. Mother offspring interactions in Zebu cattle. Reproduction in Domestic Animals, v.43, p.213-216, 2008. DOI: https://doi.org/10.1111/j.1439-0531.2008.01164.x.

PEIXOTO, M.G.C.D.; BRUNELI, F.A.T.; BERGMANN, J.A.G.; SANTOS, G.G. dos; CARVALHO, M.R.S.; BRITO; L.F.; PEREIRA, M.C.; PIRES, M. de F.A. Environmental and genetic effects on the temperament variability of Guzerá (Bos indicus) females. Livestock Research for Rural Development, v.28, 2016.

PEIXOTO, M.G.C.D.; BRUNELLI, F.A.T.; SANTOS, G.G. dos; PENNA, V.M.; MACHADO, C.H.C.; VERNEQUE, R. da S.; MACHADO, M.A.; PANETTO, J.C. do C.; LÔBO, R.B.; CARVALHO, M.R.S. (Ed.). Programa Nacional de Melhoramento do Guzerá para Leite: resultados do Teste de Progênie, do Programa de Melhoramento Genético de Zebuínos da ABCZ e do Núcleo MOET. Juiz de Fora: Embrapa Gado de Leite, 2014. 72p. (Embrapa Gado de Leite. Documentos, 168).

RAINFORTH, M. The effect of maternal nutritional restriction on fetal development and of offspring in beef cattle. Alberta Academic Review, v.1, p.1-11, 2019. DOI: https://doi.org/10.29173/ aar12.

RILEY, D.G.; CHASE JR., C.C.; OLSON, T.A.; COLEMAN, S.W.; HAMMOND, A.C. Genetic and nongenetic influences on vigor at birth and preweaning mortality of purebred and high percentage Brahman calves. Journal of Animal Science, v.82, p.1581-1588, 2004. DOI: https://doi.org/10.2527/2004.8261581x.

RING, S.C.; MCCARTHY, J.; KELLEHER, M.M.; DOHERTY, M.L.; BERRY, D.P. Risk factors associated with animal mortality in pasture-based, seasonal-calving dairy and beef 
herds. Journal of Animal Science, v.96, p.35-55, 2018. DOI: https://doi.org/10.1093/jas/skx072.

SÃO PAULO. Lei ${ }^{\circ} 11.977$, de 25 de agosto de 2005. Institui o Código de Proteção aos Animais do Estado e dá outras providências. Diário Oficial [do] Estado de São Paulo, 26 ago. 2005. p.3-4.

SCHMIDEK, A.; PARANHOS DA COSTA, M.J.R.; MERCADANTE, M.E.Z.; TOLEDO, L.M. de; CYRILLO, J.N. dos S.G.; BRANCO, R.H. Genetic and non-genetic effects on calf vigor at birth and preweaning mortality in Nellore calves. Revista Brasileira Zootecnia, v.42, p.421-427, 2013. DOI: https://doi.org/10.1590/S1516-35982013000600006.

SCHMIDEK, A.; MERCADANTE, M.E.Z.; PARANHOS DA COSTA, M.J.R.; RAZOOK, A.G.; FIGUEIREDO, L.A. de. Falha na primeira mamada em bezerros Guzerá: fatores predisponentes e parâmetros genéticos. Revista Brasileira de Zootecnia, v.37, p.998-1004, 2008. DOI: https://doi.org/10.1590/S151635982008000600007 .

SCHMIDEK, A.; PARANHOS DA COSTA, M.J.R.; MERCADANTE, M.E.Z; TOLEDO, L.M. de. The effect of newborn calves vigour in their mortality probability. In: INTERNATIONAL CONGRESS OF THE SOCIETY OF APPLIED ETHOLOGY, 40., 2006, Bristol. Proceedings. Bristol: ISAE, 2006. p.221. Edited by M. Mendl, J.W.S. Bradshaw, O.H.P. Burman, A. Butterworth, M.J. Harris, S.D.E. Held, S.M. Jones, K.E. Littin, D.C.J. Main, C.J. Nicol, R.M.A. Parker, E.S. Paul, G. Richards, C.M. Sherwin, P.T.E. Statham, M.J. Toscano and P.D. Warriss.

STĚHULOVÁ, I.; ŠPINKA, M.; ŠÁROVÁ, R.; MÁCHOVÁ, L.; KNĚZ, R.; FIRLA, P. Maternal behaviour in beef cows is individually consistent and sensitive to cow body condition, calf sex and weight. Applied Animal Behaviour Science, v.144, p.8997, 2013. DOI: https://doi.org/10.1016/j.applanim.2013.01.003.

TAYLOR, R.F.; MCGEE, M.; CROSSON, P.; KELLY, A.K. Analysis of suckler cow reproductive performance and its contribution to financial performance on Irish beef farms. Advances in Animal Biosciences, v.8, p.64-66, 2017. Supplement 1. DOI: https://doi.org/10.1017/S204047001700173X.

TURNER, S.P.; JACK, M.C.; LAWRENCE, A.B. Precalving temperament and maternal defensiveness are independent traits but precalving fear may impact calf growth. Journal of Animal Science, v.91, p.4417-4425, 2013. DOI: https://doi.org/10.2527/ jas.2012-5707.

VASSEUR, E.; RUSHEN, J.; PASSILLÉ, A.M. de. Does a calf's motivation to ingest colostrum depend on time since birth, calf vigor, or provision of heat? Journal of Dairy Science, v.92, p.3915-3921, 2009. DOI: https://doi.org/10.3168/jds.2008-1823.

VEISSIER, I.; CARÉ, S.; POMIÈS, D. Suckling, weaning, and the development of oral behaviours in dairy calves. Applied Animal Behaviour Science, v.147, p.11-18, 2013. DOI: https://doi.org/10.1016/j.applanim.2013.05.002.

WEAVER, D.M.; TYLER, J.W.; VANMETRE, D.C.; HOSTETLER, D.E.; BARRINGTON, G.M. Passive transfer of colostral immunoglobulins in calves. Journal of Veterinary Internal Medicine, v.14, p.569-577, 2000. DOI: https://doi.org/10.1111/j.1939-1676.2000.tb02278.x.

ZIPP, K.A.; BARTH, K.; KNIERIM, U. Behavioural response of dairy cows with and without calf-contact to hair of own and alien calves presented in the milking parlour. Applied Animal Behaviour Science, v.180, p.11-17, 2016. DOI: https://doi.org/10.1016/j.applanim.2016.05.001. 